\title{
Non Political Grassroots Leadership and Sustainable Development in Nigeria: An Analysis of Challenges and Policy Proposals
}

\author{
Prof. Maduabum, $C$. \\ Dr. Akhakpe Ighodalo \\ Department of Public Administration
}

Faculty of Management Sciences, Lagos State University, Ojo, Nigeria

Doi: 10.19044/esj.2018.v14n5p268 URL:http://dx.doi.org/10.19044/esj.2018.v14n5p268

\begin{abstract}
The paper argued that Nigeria is inundated with rich human and material resources begging to be harvested by purposeful, creative and innovative leadership. Development that is based on the cultural values of the people and takes a bottom-top approach, holds the key to unlocking the development potentials and at the same time resolve the quagmire the country has found itself since flag independence in 1960. Rather than seek to replicate Western prototype of development, empowering the people through Community Based Organizations (CBOs) to make the right choices and change their situation in such a way that each stage of their lives is increasing better than the proceeding one, is the basis of sustainable development. This can only be realized however, if the right caliber of leadership is in charge of affairs and able to harness and utilize available resources for the growth and development of the grassroots. With the use of the Basic Need Theory (BNT), the paper analyzed issues of grassroots non-political leadership and the role it can play in sustainable development. Drawing experiences from developed and developing countries in the globalize era, it concluded that grassroots leadership cannot successfully address challenges of sustainable development, unless, among other things, it embraces global best practices cultivated and harvested from within Nigeria in the globalize era, promote democracy within CBOs, encourage popular participation, good governance at the grassroots, and financial independence and transparency in the usage or management of financial resources.
\end{abstract}

Keywords: Leadership, Non-Political Leadership, Sustainable Development, Community Based Organization, Popular Participation and Grassroots 


\section{Introduction}

Nigeria boasts of some of the richest human and material resources in the world. These potentials in most cases lie fallow waiting to be harnessed for the benefit of its teeming population due to poor leadership (Rapley, 2007). However, for these resources to be effectively harnessed for the growth and development of the country and its people, visionary, exemplary and selfless leaders are needed. All developed countries of the world today have at one time or the other, had leaders who were able to take on challenges of growth and development in their respective countries as issues that should be overcome and did everything within their abilities to ensure that they subdue these challenges to pave the way for individuals and groups to actualize their innate potentials and abilities for societal transformation.

One of these challenges that developing countries face is how to create the context of stable political environment for socio-economic programmes to be carried out. Also, there is the need to create a system of government that will facilitate freedom of choice and liberty for the people to pursue their individual and corporate interests. Once these enabling environments are created, it becomes easy for the people to confront and resolve challenges facing them by using resources within their environment to create a condition of life where each stage is progressively better than the proceeding one.

Leadership is crucial to realizing any giant stride in pursuit of development, anywhere in the world. Nigeria is not an exception. There is the general believe all over the world that development is not the sole responsibility of government. In situations where government fails in its duties to promote development, community development efforts are encouraged to complement government efforts. This is where grassroots leadership comes in handy. There is the feeling among Nigerians that positive non political grassroots leadership remains elusive in the country especially in the area of administration and management of resources. Historically, Nigerians are known to be their brother's keeper. By doing things in common to mitigate challenges of development and promote corporate coexistence (Osaghae, 1994). Identification and nurturing of positive non-political grassroots leadership appear, key to ensuring sustainable development at the grassroots where majority of Nigerians live and remains the cradle of development in Nigeria. The paper applied the histo-analytical method with some sprinklings of empirical observatory method.

\section{Non-Political Leadership and Sustainable Development: Conceptual and Theoretical Frameworks}

Leadership can be found in diverse groupings and organizational settings. Some of the variants of leadership include: political leadership, traditional leadership, spiritual leadership, and non-state leadership (Ihunna, 
2005). Unlike political leadership or State leadership, non-political leadership is not a very popular term in the social science discourse due to the central role political leadership has come to play in the life of the people in the country. However, non-political leadership has become important in view of the neglect grassroots governance has suffered in Nigeria.

Generally speaking, leadership has three main characteristics. Leadership as an attribute of position; characteristic of a person and category of behavior (Nwachukwu, 2007). It is in these uses of the concept that leadership is key to grassroots development. Some people are gifted and they bring this gift to bear on the act of managing men and resources toward achieving set goal. They therefore, make success out of anything they handle. Non-political leadership is those at the head of organized efforts to bring about the achievement of commonly identified purposes in the areas of, among others: health care delivery, poverty reduction and infrastructure development education (Ihunna, 2005).

Non-political grassroots leadership is found in the non-stale sector such as civil society constituents like: Community - Based Organizations (CBOs) and Non-Governmental Organizations (NGOs). In Nigeria, the grassroots has a lot of challenges confronting it, among which are: poverty, illiteracy, lack of portable water, good roads and poor health care delivery system. This situation may not be unconnected to years of rural neglect due partly to the urban bias of successive governments that prioritize major cities and urban centres to the detriment of the rural areas. In the light of this, Nigeria today boost of several grassroots organizations which offer leadership that is grassroots-focused and constituted through popular participation to achieve the much needed socio-economic and cultural development at the grassroots. It is expected that this approach will bring about people-centered sustainable development at the grassroots.

Development as a concept refers to the ability of a people to use their cultural values to change their environment and lives (Rudeback, 1997). However, this process should not be pursued in a manner' that is injurious to future generations. In other words, development should be pursued in such a way that takes care of the present needs of the people without hindering the ability of future generations to cater for their own needs (Rudeback, 1997, United Nations, 2015). This means development should be sustainable. Sustainable development is then seen as "that development that meets our present needs without compromising the ability of future generations to meet their own needs (UN/ISDR, in Ayeni, 2010). The United Nations has gone a step further to identify three recursive elements which should work together to ensure sustainable development. These are: economic development, social development and environmental protection (Mekeown, 2002; UN General Assembly, 2015). Ayeni (2010) argues that these three components must be 
conceptualized together, planned together and implemented together to achieve the desired results.

Development can only make sense to a people when they are involved in the process of decision making through the bottom - top approach. Popular participation is therefore, crucial to development. Popular participation is seen here as the active involvement of the people in a process of setting goals and making decisions not just the acceptability of end results which satisfies the need to participate (Ake, 1994). This view on popular participation aligns with the democratic principles of freedom, equality, consent and liberty. Popular participation therefore, is predicated on "the social nature of human being and the organic character of society' (Ake, 1994).

The non-political variant of leadership is base on the assumed absence of minimal presence of misconduct, corruption and personal interest in the discharge of the common good (Ihunna, 2005). In other words, politics in this realm is assumed to be sufficiently ridden of the objectionable features of the civic public realm such as: waste, corruption, violence, and other repellent ills of politics. This variant of leadership sign-posts selfless, accountable and responsive services that serve the public interest. As Ihunna (2005) persuasively argues:

This crystallizes the importance of an obligatory system of 'reciprocal norms between followers and leaders. In this wise, duties and obligations are geared towards achieving commonly identified purposes. To this extent, objective performance is crucial in the quest to retrieve the common good for the people.

This obligatory system of reciprocal norms that serve as springboard for achieving the common good, was largely neglected by post-colonial political economy in much of Africa. Development was equated with economic growth. Thereby inaugurating a system of economic growth that is not translated into sustainable socio-economic development.

Preserving human and material resources for present and future generations means such development is sustainable. Therefore, sustainability means ability to evolve scheme for socio-economic and environmental aspects of human activities with a view to improving the people's living standard (Anice and Igwe, 2016). Thus, the political, social, economic and environmental aspects or elements of sustainable development should all work together for the good of man and the society they live in. Successive governments in the country have always come up with sustainable development programmes that were never sustained. In view of the several performance failure of governments' can non-political grassroots leadership in the country come to the rescue or do things differently to provide the basic needs of the citizens, in the areas of: health care, education, portable water, good roads and transportation? These issues are so central to development that 
the United Nations in 2015 came up with fifteen years plan the attainment of for sustainable development. Seventeen (17) goals are set out to be accomplished by nation-state (The UN, 2015). Though the will and capacities to attain these goals may deter from country to another. Given the state of development in the country today the basic needs of the people should be prioritized by the state grassroots leadership and non-state actors.

The dominant economic theory of the $60 \mathrm{~s}$ and 70 s popularized by Walter Rostow, measured growth as a rise in the national income per head (Toyo, 2010). Unfortunately, "the relatively rapid economic growth witnessed by the country from 1973 to the early 80 s, did not yield visible spread or trickle-down effects of its benefits among the poor and especially those residents in the rural areas" (Alernike and Olumodeji, 1998). Indeed, Nigerians at the grassroots became worst off in their living standard. To interrogate the subject matter of this study, several theoretical approaches could prove useful when applied to the issues of leadership and sustainable development. One of them is the Base Need Approach (BNA). This theory centres on the essential needs of the people at the grassroots. Yet, it may not be far-reaching enough because it merely scratches the surface of the existing development objectives and processes in Nigeria. The exigential social conditions of the people of the grassroots communities call for expansion of this approach to enable it tackle challenges of the grassroots which include: powerlessness of the people, excruciating poverty and disempowerment of the vast majority of Nigerians to participate in decision making (Alernike and Olumodeji, 1998). The Basic Need Approach to grassroots development should therefore, be conceptualized to make the basic need package more inclusive and heuristic to retrieve and release the" creative energies and potentials of the (grassroots) people held down and crippled by centuries of degrading oppression and servitude" (in Alernike and Olumodeji, 1998).

\section{The Context of Non Political Grassroots Leadership and Development}

Non - political grassroots leadership is an instrument in the communal style of socio-economic development in the pre - colonial societies in Africa. At this early stage of their existence, production of goods and services were for subsistence and there was no appropriation of surplus that carne with surplus production and the need to meet demands of the appropriators of surplus production (Toyo, 2010). In this era, Africans had lived in communities where they were able "to direct their energy to collective selfrealization through common enterprise by which the community seeks to reproduce itself at increasing higher level of spiritual and material well-being. It was here that people cooperated, sacrificed and worked towards a better society by combating crime, improving health care and building schools" (Ake. 1994). 
What could be regarded as authentic developments at this point in time were based on the cultural values of the people who were able to release their innate abilities to enhance their spiritual and material conditions (The Political Bureau Report, 1987). Also, the people cooperated with one another and joined hands to create a better socio-economic condition for the whole of the society. In most African traditional societies, everyone was his/her brother's keeper. Everyone contributed according to his ability and needs, not desires. As the Political Bureau Report (1987) put it:

Although there was exploitation of the peasant, each polity operated with a basic minimum sense of fairness and justice for each member of the community. Thus, each (community) possessed a moral order that governed affairs. The moral order, predicated on the welfare and well- being of the entire community, enabled pre-colonial Nigeria to cope with crisis, manage conflicts and confronts challenge from within and without.

The moral order of this era was expedient for development and corporate existence of the people. Conversely, any system that is based on injustice is prone to incessant crises and conflicts. Thus, the pursuit of the general welfare and well- being of the people became the fulcrum of stability and progress in the socio- economic and political order of this era. Also, political and non- political leadership carried out their duties on the basis of consultation and consensus among the people within the polity. In other words, the people were actively, involved in governance. Those in position of authority ensured that they do not attract the displeasure of the people. These rules therefore, demand that there was an intricate balance between power and authority on the one hand and service and accountability on the other (The Political Bureau Report, 1987).

In the post-colonial era, however, the emergent State declared its intention to create an egalitarian society where the welfare and well-being of the individual will be enhanced through "providing better educational facilities, housing, health facilities, job creation and a rising standard of living for the people as a whole" (William, 1980). These goals and objectives could be said to be well intentioned. But the ideological framework within which these developmental goals are predicated could be said to be faulty. For example, the mixed economy ideology the country embraced at independence assumes that growth proceeds distribution thereby justifying inequality as an avenue to reach the universal goal of development (William, 1980). This paradigm of development in Nigeria has brought social inequality and disempowerment to the people in its efforts to make qualitative choice about their needs and future. 
The Structural Adjustment Programme (SAP) and globalization are public policy instruments aim at deregulating the economy and allow free flow of goods and services to make the public sector and economy more efficient and effective (Stightz, 2007, Akhakpe 2014, 2016). However, these efforts appear to have failed have been unable to reduce the growing rate of poverty, social inequality, economic underdevelopment and environmental degradation currently going on especially in mineral bearing and producing rural communities in Nigeria. The urban centres also suffer similar faith to a larger or lesser degree. In the Niger-Delta region of Nigeria, for example, there has been increased exploitation of renewable and non-renewable resources, intensifying in the process degradation of the environment and sources of livelihood of the people (Akhakpe, 2006, 2014). Crises and conflicts these activities spawn, have not only led to lose of lives and properties, but has brought social insecurity to the people of the affected areas (Akhakpe 2014, Fajoyomi, 2012). The failure of the people to reproduce themselves in their environment as a result of ecological hazards and state led exploitation activities have led to among others increased poverty and food insecurity in the affected areas of the country.

From all indications, the State in Nigeria has demonstrated its lack of capacity to mid wife sustainable development. Different accounts have described the State in Africa as weak, failed and or fragile. Human and Ratner (in Fajonyomi, 2012) described a failed State as being "utterly incapable of sustaining itself as a member of the international community. Similarly, Woodward (in Fajonyomi, 2012) posts that "state failure is in its inability to make collective decisions and to enforce them, if necessary". A weak State show-case similar attributes but appears to spread these inabilities to different aspects of societal life. As Rothera (in Fajonyomi, 2012) puts it:

In weak States, the ability to provide adequate measure of other political goods is diminished or diminishing. Physical goods is diminished or diminishing. Physical infrastructure networks have deteriorated. Schools and hospitals show signs of neglect, particularly outside the main cities (the grassroots). GDP per capital and other critical economic indicators have fallen or falling sometimes dramatically, levels of viral corruption are embarrassingly high and escalating. Weak state usually honour the rule of law precepts in the breach.

The declining ability of the State in Nigeria to provide the basic necessities of life for the people makes it expedient for non-political grassroots leadership through CBOs and NGOs to complement efforts of the political leadership at various levels of government. In pursuance of this goal, popular participation of the people in decision making and implementation could be 
crucial for grassroots sustainable development. How this can be done to provide the basic needs of the people is the focus of discussion in the section that follows.

\section{The Interface Between Non-Political Grassroots Leadership and Sustainable Development}

Several decades of development planning and implementations, it would appear have failed to address the pressing concerns of Nigerians for improved welfare and well-being. Also, for many years, non political grassroots leadership appeared to have left their primordial setting for political appointments at the Federal and State levels thereby alienating the people of the grassroots. Such alienation of the mass populace from their leaders, has rob the development process of a vital support base and ingredients which facilitates genuine development. The old paradigm of top-bottom approach to development has produced uneven distributing of wealth, power, exclusive access to essential resources, as well as increase level of exploitation in the society. This has made the search for a people-centered development paradigm that focuses on the basic need of the people, imperative. This paradigm shift is necessary if sustainable development is to be realized at the grassroots in the country.

In the light of this, a new development model that is sustainable is perceived as one of the ways to bring back genuine development to the people of the grassroots. Sustainable development contains three primary factors: economic, social and environment (Oyeshola. 2008). Economically, a sustainable system should be able to produce goods and services which would maintain manageable socio- economic development while at the same time ensure sectorial balance in economic activities (Oyesola, 2008). Environmentally, a sustainable development should emphasize environmental friendly practices in exploitation of renewable and non-renewable resources (Oyesola, 2008). The social angle to it, addresses distributional issues, gender equity, adequate provision of social services such as: health, education and political accountability, transparency and participation (Ayeni, 2010).

Non-political grassroots leadership has a crucial role to play in the realization of these goals of sustainable development. Both at the individual and collective levels, it can mobilize support for programmes and policies which are aimed at resolving challenges posed by the present economic, sociopolitical and environmental conditions in a globalize system. The good will of these leaders alone can help promote efforts at sustainable development. Some grassroots leaders provide resources for running organizations, in which case they may be operated as personal ventures without relying on the state dwindling resources. In terms of organization, some Community Based Organizations (CBOs) are better structured. Leadership in this context, is 
determined by elections or appointments usually for a specified period of time. In some CBOs, criteria are laid down for appointing their leaders while in others; it is based on primordial sentiments. Though in most cases, women in such organization are poorly represented and play minimal roles in decision making (Dogo, 2005).

Also, finance is critical to the operations of the CBOs and NGOs sector. The bulk of CBOs finance mainly comes from contributions of members in form of levies, fees, dues, etc. Also, their branches in the Diaspora could contribute money and send same to CBOs in villages or towns for developmental purposes (Dogo, 2005). Leadership of Non-Governmental Organizations tend to be well organized with offices in towns, cities and villages. They are heavily donor-driven and donor- dependent. Donor agencies usually lay down criteria for giving funds to NGOs. This practice in some cases has led to the loss of autonomy in decision-making and the use of resources in pursuing nebulous goals of such organizations (Dogo, 2005). The fact that they are supported by donor agencies could mean that accountability and due process in their operations may be followed to meet the basic needs of the people.

Generally speaking, funds generated by CBOs and NGOs are used for carrying out development projects like the building of schools, hospitals, cottage industries, digging of bore-holes, etc (Dogo, 2005). Other critical roles played by NGOs/CBOs include: mobilizing people to develop self-confidence in taking initiative; compliment government efforts at generating new ideas as input for its development plans, empower the people to exercise their rights of popular participation, freedom of association and help to promote activities that could lead to increase production and wealth creation, such as microcredit, rural employment, small and medium scale enterprises etc (Dogo, 2005).

These activities of NGOs and CBOs are expected to bring about sustainable socio-economic and environmental development at the grassroots. However, the spate of poverty and social inequality in the country is an indication that not much has been realized through their programmes and projects (Egbe, 2004). What factors explain these developments? To these issues we direct our analysis in the section that follows.

\section{Non Political Grassroots Leadership and Challenges of Sustainable Development}

There are several factors militating against efforts by grassroots leadership to realize sustainable development in the country. In this section, we shall examine some of the challenges facing CBOs in the pursuit of sustainable development in the country. 
In the first place, poverty of grassroots leadership remains one of the most daunting challenges of sustainable development in developing countries. Most CBOs and NGOs are administered as personal estates by their leaders/founders. Some leaders of these organizations operate without internal democracy. This practice stifles freedom of choice and initiative in these organizations. Also, most grassroots leaders have a sit-tight mentality which does not allow for new ideas, fresh initiative, change in the style of leadership and innovation. Moreso, rather than concentrate on developmental efforts, some grassroots leaders occupy themselves with boot-licking donor agencies or blackmailing others NGOs/CBOs leaders in other to be favoured by donor agencies.

Real poverty is still rampant in the country. Several studies both within and outside the country have shown the poor state of human welfare and wellbeing. In spite, of its abundant wealth, Nigeria ranked 40 out 119 developing countries on the global hunger index, according to report released by US based International Food Policy Research and a German NGOs-Agro-Action (Punch 10/11/2006). Similarly, the United Nations Development Programme -Human Development Index ranked Nigeria 159th out of 177 countries on quality of life index in the world (Punch 13/11/2006). Sub-Saharan Africa can be said to be the bedrock of alarming poverty traps as shown in falling incomes, growing health crises and deteriorating natural environment (Punch 21/9/2011).

The global economic order has not favoured countries of the South. It is based on unequal economic relations which have left countries in the SouthSouth in perpetual dependence on advanced economies. Balance of trade and payment have always been unfavourable to developing countries because of the structure of the world economic order (Tayo, 2010). Also, the current global economic crisis is a product of the crisis inherent in the capitalist system that thrives on appropriation of surplus value (Toyo, 2010). Efforts at resolving the global economic crisis has seen "the unprecedented ascendancy of neo-liberalism as the driving force behind global and regional economic development" (Saravanamuttu, 2001). Yet, neo-liberalism has not been able to bring about sustainable development particularly at the grassroots in most developing areas of the world. The promise of globalization in the 1990s did not quite translate into corporate economic growth and development in Nigeria. The East-Asian countries also, were not left out of the backlashes of globalization. As Saravanamuttu notes:

These broad economic and financial development of globalization in1990s have provided the context, if not the consequences, for the spectacular events of 1997 and 1998 which have come to be called East- Asia's financial crisis turmoil and meltdown. 
While the global economic 'meltdown' can be felt in virtually all countries of the world, not all countries have the ability to manage its effects. While countries like Malaysia and Singapore, for instance, have been able to mitigate its negative effects, others like Nigeria have seen the intensification of poverty, hunger, violence and infrastructural decay.

Also, paucity of funds has been a major challenge to leadership role in the sustenance of grassroots development. The failing state in Nigeria lacks the political will and financial strength to promote grassroots development (Fajonyomi, 2012). With dwindling resources in the polity, occasioned by unstable oil prices, corruption and mismanagement, CBOs and NGOs have had to look outside for funds either from their members in the diaspora or aid from donor agencies. However, external sourcing of funds by grassroots leadership has dealt a big blow on the autonomy of these organizations and brings to question the genuineness of their objectives. As is often said, "he who pays the piper dictates the tones".

This development has two not unrelated consequences. In the first place, most programmes carried out by the NGOs/CBOs leaders at the grassroots are not really indigenous in content. They are fashioned after the example of the advanced societies. This alienates the supposed beneficiaries of these programmes. The socio-cultural demands of Nigerians are not the same with those of the more advanced economies. It would seem these leaders arrogate to themselves the right to speak for the people of the grassroots rather than allow them determine what they want and how they want them. In essence, such imposed projects are unlikely to achieve their goals.

Related to the above point, is the issue of originality of the work of most CBOs and NGOs. This could be as a result of the external orientation of most of these programmes which lead to failure to harness the rich sociocultural and economic potentials of the grassroots. Naturally, the people would feel alienated from what they supposed to benefit from them thereby robbing such projects of the vital support base that could lead to their successful implementation. Consequently, most NGOs/CBOs and their leaders could be said to be "uncritically following paths prescribed by foreign theories and precepts" (Dogo, 2005). All these challenges have impacted negatively on grassroots leadership abilities to pursue and achieve the basic needs of the people and sustainable development at the grassroots.

\section{Non-Political Grassroots Leadership and Sustainable Development: Policy Proposal for Sustainability}

We have identified some challenges facing grassroots leadership in its efforts to promote sustainable development in Nigeria. As enormous as these challenges may look, they are not insurmountable. In this section of the discourse, we shall examine some policy proposals which could be leveraged 
on to promote sustainable socio-economic and environmental development through the instrumentality of grassroots leadership in Nigeria.

The political culture of Nigeria has for many years been negative. Some of these negative elements in the country's political culture include: intolerance, violent conflict, neo-patrimonialism, ethnicity, religious fanatism, and so on. This has been largely due to years of military/authoritarian rule in the country. However, the situation is gradually changing and patience is required for grassroots leadership to begin to harvest the vast potentials in the land for sustainable development. Therefore, rather than seek to co-opt CBOs or undermine their activities and programmes, government(s) should aim at tapping from their closeness to the people to promote developmental efforts particularly, at the grassroots. Also, the old development paradigm in Nigeria and other countries in Africa is gradually giving way for a new paradigm that hinges on empowerment of the people to make choices and carry out bottom top approach to development. As Ake (2000) puts it, such development paradigm aims at:

Making the people the end and means of development by this approach development ceases to be what the government and international development agencies do for the ordinary people, but what the ordinary people do for themselves. It becomes their possession, their learned experience, not a received experience. In so far as they posses development and become its end, the content of development can be potentially, their progressive empowerment and self-realization.

It is this people-centric approach to development that can bring about sustainable socio-economic development. This will encourage "local commitment and acknowledged benefit to pay the price of continuation of project activities" (Olawoye, 2008). Donor-driven projects could suffer neglect once funds from supporting donors dry up. Thus, there is the need to design extension services that can improve the income of the grassroots population to enable them contribute financially to protect in their communities. Also, funds can be raised from members' dues and free will donation.

Also, it is important to stress the imperative of increasing the level of peoples' participation in decision-making, project design and development, implementation and evaluation (Olawoye. 2008). The level of popular participation should be able to promote local ownership of project, thereby mitigating the effect of foreign oriented programmes and give a sense of ownership, maintenance and care for grassroots, projects, programmes and facilities. Moreso, intervention projects in rural localities should involve all 
sectors of the grassroots population in order to avoid their alienation from the development process.

Furthermore, environmentally friendly activities should be emphasized when addressing the development concerns of the grassroots population. Their leadership should promote and encourage Environment Impact Assessment (EIA) practice before, during and after such projects are carried out, to reduce, if not eliminate, cases of environment degradation and other ecological hazards which hinder the pursuit of sustainable development at the grassroots. While leadership at the grassroots may be willing to bring about development in the different communities, their efforts should not further endanger the people by carrying out programmes which are injurious to the people's welfare and well- being.

Grassroots leaders need basic infrastructures to facilitate their work. But basic infrastructures are in very bad shape in Nigeria Roads, water supply, electric power supply, among others are in a parlous state. All these should be improved upon in order to facilitate the work of grassroots leadership in bringing about sustainable development. Also, information or database on grassroots challenges in Nigeria, should to be updated to avail grassroots leadership with adequate background information to work with at any given point in time. With better education and sensitization programmes for grassroots inhabitants its challenges will gradually be resolved.

It is important that the evolving democratic dispensation in the country should be sustained because no section of the country can get its development priorities right unless it gets its politics right. Political stability is therefore, critical to grassroots development. The democratic system is best suited for bringing out competent and legitimate leaders to the public domain that can get the people to promote developmental activities. It also, makes grassroots leaders to be transparent and accountable to the people. All these are necessary ingredients for sustainable development at the grassroots.

Poverty is a major if not the principal obstacle to sustainable development in developing societies. It would seem Nigerians are in a vicious cycle of poverty. Majority of Nigerians live below the poverty line of less than one dollar per day (Bello, 2006). Malnutrition, hunger, disease, poor health facilities and illiteracy among others, are common phenomena in Nigeria. It is in recognition of this situation that successive governments in Nigeria have initiated policies and programmes to attenuate the negative effect of this socioeconomic scourge. But it would seem that much still have to be done in order to reduce the debilitating effects of poverty in the country. In this regard, women, children and other highly vulnerable groups have to be given greater attention in all efforts to reduce poverty in the country in order to achieve sustainable socio-economic and political development. 
Positive leadership is needed to bring together human and material resources to effect social change at the grassroots. Certain elements have to be mixed up in this kind of leadership in order for it to be productive. Burns (1978) posits that:

The premise of this leadership is that whatever the separate interest persons might hold, they are presently or potentially found in the pursuit of higher goal, the realization of which is stated by the achievement of significant change that represent the collective or pooled interest of the lenders and followers.

What this means is that, leadership should be selfless and visionary, ready to subordinate their personal interests for the group interests. Both material and human resources cannot be put into productive use on their own, unless they are combined effectively by leaders to achieve grassroots development. Unless this is done to reflect the modern trend in the globalize era, development may remain far-fetched. Such trends demand the appropriation and use in the country of international best practices base on the rule of law and transparency in governance.

\section{Concluding Remarks}

Sustainable development is an all encompassing phenomenon which makes it a complex task to accomplish. Grassroots leadership has enormous task on its hands in its attempt to pursue this very important activity in the lives of the people and the entire society. How they carry out these activities aimed at sustainable development varies from one grassroots community to another. The most common and long lasting of these efforts could come through Community Based Organizations (CBOs). This approach to community development is predicated on involving the people in the efforts to bring development to them. Their actions and activities may vary but they aim at providing basic services to the people. At a broader level, it involves Non-Government Organizations (NGOs). They present a bigger platform for carrying out grassroots development programmes and at the same time confront challenges of sustainable development.

The leadership of these various organizations the study observed, are either selected or elected. Yet, they share certain common characteristic like selflessness, inclination towards external funding, relatively untrained staffs, etc. These features partly account for the slow pace of development at the grassroots in Nigeria. In the light of these challenges several remedial steps are suggested. These include: among others internal democracy in these organizations popular participation in decision making, reduction in poverty, provision of basic infrastructural amenities, and better funding. Once these steps are carried out, sustained development through grassroots leadership would be realized in Nigeria. 


\section{References:}

1. Ake, C. (1994). Democratization of disemployment in Africa" Center for Africa Social Sciences. Accessional Monograph No.1 Lagos: Malt House Press Ltd.

2. Ake, C. (2000). The feasibility of democracy in Africa. Dakar: Codesria,

3. Akhakpe, IB. (2006). Oil pollution and environment conflict in the Niger-Delta Region: A framework for conflict management in A. Saliu et al (Eds). Democracy and development in Nigeria economic and environmental issue. Lagos: Concept Publishers.

4. Akhakpe, IB. (2014). Public policy, interest group and sustainable development in Nigeria. Review of Public Administration and Management 3(4).

5. Akhakpe, IB. (2016). Public policy and sustainable national development in Nigeria's Fourth Republic: Challenges and possibilities. International Journal of Management Perspective 3(1).

6. Alernike, E. and Olumodeji, E. (1998). Basic needs approach to rural development and radical skepticism: A critique", Nigerian Journal of Social Work, 2.

7. Aliya, M. \& Isa M. (2016). A strategic management of human resources for sustainable development in Nigerian.

8. Amure, G. \& Igwe, S. (2016). ICT resource management and sustainable development: An inquiry into the causes of sustainable development. in Nkamnebe (Ed) Resource management for sustainable development proceedings Benin City: $9^{\text {th }}$ national conference of the Academy of Management Nigeria, July.

9. Ayeni, A. (2010). Sustainable development through international cooperation in research and education in L. Popoola \& O. Olorunnisola (Eds). Contemporary issues in sustainable development: Lessons for, and challenges to Nigeria. lbadan: The Post Graduate School University of Ibadan.

10. Bello, M. (2006). Reflections on poverty reduction strategies in A Saliu et al (Eds.) Democracy and development in Nigeria. economic and environmental issues. Lagos: Concept Publishers.

11. Burns, A. (1978). Leadership, London: Harper-Colophon Book.

12. Dogo, B. (2005). Leadership in development organization in the nonstate sector. Tentative comments from personal experience in B. Olukoshi, et al (Eds.) Nigeria's search for positive leadership, lbadan: University of lbadan.

13. Egbe, M. (2004). The state and civil society in Nigeria: A case study of the Movement for the Survival of the Ogoni People (MOSOP), Lagos: Nigerian Institute of International Affairs. 
14. Federal Government of Nigeria (FGN) (1987). Report of the Political Bureau Abuja: MAMSER.

15. Fajonyomi, S. O. (2012). When the State goes to sleep: Of citizens and State relationship: LASU inaugural lecture Series Lagos: Lagos State University.

16. lhunna, O. (2005), The paradox of non-political leadership: Theoretical and empirical insights from individual, political institution in Nigeria" in A. Olukoshi et al (Eds.) Nigeria's search for positive leadership: Ibadan: Ibadan University Press.

17. Mekeown, (2002). Education for sustainable development. Toolkit Version 2.0 (http://www .esdtoolkit.org/Discussion/ default access May, 2009.

18. Nwachukwu, C.C. (2006). Management: theory and practice, Onitsha: Africana First Publishers Limited.

19. Olawoye, J. (2008). Sustainable rural development: Challenges, opportunities and lesson from Nigeria" in I. Popoola \& O. Olorunnisola (Eds.) Contemporary issues in sustainable development: Lesson for and challenges in Nigeria, 2. Ibadan: The Post Graduate School University of Ibadan.

20. Osaghae, E. (1994). Introduction: Between the individual and the State in Africa: The imperative of development in E. Osaghae (Ed) Between state and civil society in Africa. Dakar: Codesira.

21. Oyeshola, D. (2008). Sustainable development: Issues and challenges for Nigeria. Ibadan: Daily Graphics (Nig) Limited.

22. Rapley, J. (2007). Understanding development theory and practice in the Third World, London: Lynne Rienner Publishers.

23. Rudeback, I.C. (1997). To seek happiness: Development in a West African village in the era of democratization. Review of African Political Economy 14(11).

24. Saravanamuttu, J. (2001). Globalization, capital and governance in a newly industrializing plural society: Malaysia during the 90's in S. Maclean, F. Quadir \& T. Shaw (Eds.) Crisis of governance in Asia and Africa. Aldershot: Ashgate Publishing Limited.

25. Stightz, J. (2007). Making globalization work. New York: W.W. Norton and Company Inc.

26. The Punch Newspaper (2006). Lagos: November 13.

27. The Punch Newspaper (2006). Lagos: October 10.

28. The Punch Newspaper (2011). Lagos: September 21.

29. Toyo, E. (2010). The poverty question: The constitution: A Journal of Constitutional Development. 10(3) September. 
30. United Nations General Assembly (2015). Sustainable development: Managing and protecting our common environment, World Summit Outcome.

31. William, G. (1980). State and society in Nigeria. Idanre: Afrografika. 